HoST - Journal of History of Science and Technology

Vol. 14, no. 2, December 2020, pp. 1-12

10.2478/host-2020-0012

\title{
Introduction: The Fabulous 1930s in the History of Science and Technology
}

\author{
Ana Simóes \\ Centro Interuniversitário de História das Ciências e da Tecnologia (CIUHCT) \\ Faculdade de Ciências, Universidade de Lisboa \\ aisimoes@fc.ul.pt
}

Antonio Sánchez

Autonomous University of Madrid

antonio.sanchezm@uam.es

Historians of science and technology have been increasingly curious about the history of their disciplines, viewing the path that has been trodden thus far as a source of ideas to help renew and refresh present day concepts and methodologies. In this context of historiographical reflection, historians have looked at certain time periods, which signal specific historiographical trends or inflections. Despite being aware of the limitations and even dangers that periodization imposed by historians on the past brings, the fact of the matter is that specific "decades" in a broad sense have stood out for their idiosyncratic historiographical outlook. For instance, the 1970s have been recently dubbed as the "turn of an era" in the history of science as well as in the history 
of technology. ${ }^{1}$ The 1930s, on the other hand, have long caught the attention of historians of science and technology for a variety of reasons. ${ }^{2}$ This decade, broadly speaking-including the late 1920s and early 1940s_-was the historical period when the first words of criticism to the positivist agenda, in which Georges Sarton established the history of science as a professional discipline, were voiced. ${ }^{3}$ Further to this, the relationship between science, technology and society was brought to the forefront. The events taking place in the "long 1930s" marked the future of the history of science and technology forever: new areas and approaches were consolidated, many ground-breaking papers and books published, controversies fired and exiles shaped the discipline indelibly.

In fact, in the "long 1930s" historiographical proposals coming from very different and at times conflicting directions, were put forward, and met with a whole spectrum of reactions. As an example of that, the presentation given by the group of Soviet historians of science and technology led by Nikolai Bukharin at the 2nd International Congress for the History of Science and Technology held in London, UK, in 1931, immediately comes to mind. ${ }^{4}$ In London, Boris Hessen's radical reinterpretation of Newtonian physics and Modest Rubinstein's papers on the role of electricity in building the Soviet Union and on the relationship between science,

\footnotetext{
${ }^{1}$ Matthias Heymann, ed., "1970s: Turn of an era in History of Science?" Spotlight Contribution, Centaurus 59, no. 1-2 (2017). See especially Matthias Heymann, "Introduction to Spotlight on 1970s: Turn of an Era in the History of Science?" Centaurus, 59, no. 1-2 (2017): 1-9. For History of Technology, see John M. Staudenmaier, Technology's Storytellers. Reweaving the Human Fabric (Cambridge, Mass.: MIT Press, 1985) and from the same author "Rationality, Agency, Contingency: Recent Trends in the History of Technology," Reviews in American History 30, no.1 (2002): 168-181.

${ }^{2}$ There is an immense bibliography on this theme. It will be partly referred to and debated in the papers integrating this thematic issue.

${ }^{3}$ For a collective overview see Bernard Lightman, ed., "100 volumes of Isis: the vision of Georges Sarton," FOCUS section, Isis 100, no. 1 (2009). See also Arnold Thackray and Robert K. Merton, "On discipline building: The paradoxes of Georges Sarton," Isis 63, no. 4 (1972): 472-95; Tore Frängsmyr, "Science or history: George Sarton and the positivist tradition in the history of science," Lychnos (1973/74): 104-44; Cristoph Meinel, "Sarton, science, and the end of history," Berichte zur Wissenschaftsgeschichte 8, no. 3 (1985): 173-79; Robert K. Merton, "George Sarton: Episodic recollections by an unruly apprentice," Isis 76, no. 4 (1985): 470-86; Lewis Pyenson, "Inventory as a route to understanding: Sarton, Neugebauer, and sources," History of Science 33, no. 3 (1995): 253-82. By Georges Sarton see: "L' histoire des sciences," Isis 1, no. 1 (1913): 3-46; A Guide to the History of Science (Waltham, Mass.: Chronica Botanica, 1959); Introduction to the History of Science, 3 vols., Vol. I: From Homer to Omar Khayyam, Vol. II: From Rabbi Ben Ezra to Roger Bacon, Vol. III: Science and learning in the fourteenth century (Huntington, New York: R.E. Krieger Publishers, 1975); The history of science and the new humanism (New Brunswick, New Jersey: Transaction Books, 1988).

${ }^{4}$ Nikolai Bukharin, ed., Science at the crossroads. Papers presented to the International Congress of the History of Science and Technology Held in London from June 29th to July 3rd, 1931, by the Delegates of the USSR (London: Kniga, 1931). The new discipline's first congress had taken place two years earlier in Paris.
} 
technology and economics under capitalism and socialism, ${ }^{5}$ certainly became emblematic of an approach which took the embedment of science and technology in society seriously. ${ }^{6}$ For better or for worse, this shaped what came to be known as Marxist history of science. ${ }^{7}$ This approach deeply influenced many of the British scientists who attended the meeting, in terms of their views on science and science policy_among whom stood John Desmond Bernal and Joseph Needham. ${ }^{8}$ It influenced yet other European intellectuals, of the Vienna Circle, of the Frankfurt School, or even intellectuals who did not belong to any particular philosophical school, such as Franz Borkenau and Henryk Grossmann, to name just a few. ${ }^{9}$ Influenced by the Vienna Circle was Edgar Zilsel known for the "Zilsel Thesis," introduced on the public scene for the first time at the Fifth International Congress for the Unity of Science, held at

\footnotetext{
5 Modest Rubinstein, "Relations of Science, Technology, and Economics under Capitalism, and in the Soviet Union" and "Electrification as the basis of the Technological Reconstruction in the Soviet Union," in Bukharin, Science at the crossroads, 41-66 and 115-45. Rubinstein's paper on electrification echoes Lenine's slogan "Communism = Soviet Power + Electrification of the whole country," which was at the core of the GOELRO plan, the first Soviet plan for national economy and development that became the prototype for subsequent Five-Year Plans drafted by the State Planning Commission (Gosplan). Rubinstein was himself a member of the Presidium of Gosplan.

${ }^{6}$ Boris Hessen, "The Social and Economic Roots of Newton's Principia," in Bukharin, Science at the crossroads, 147-212. See also Loren Graham, "The Socio-Political Roots of Boris Hessen: Soviet Marxism and the History of Science," Social Studies of Science, 15, no. 4 (1985): 705-22; Gideon Freudenthal and Peter McLaughlin, eds., The Social and Economic Roots of the Scientific Revolution: Texts by Boris Hessen and Henryk Grossmann (Dordrecht: Springer, 2009); Gerardo Ienna and Giulia Rispoli, "Boris Hessen at the Crossroads of Science and Ideology," Society and Politics, 13, no. 1 (2019): 37-63.

7 Jerome Ravetz and Richard S. Westfall, "Marxism and the History of Science," Isis 72, no. 3 (1981): 393-405; Graham, "The Socio-Political Roots of Boris Hessen;" Helena Sheenan, "Marxism and Science Studies: A Sweep through the Decades," International Studies in the Philosophy of Science 2, no. 2 (2007): 197-210; and Gideon Freudenthal and Peter McLaughlin, "Classical Marxist Historiography of Science: The Hessen-Grossmann-Thesis," in Freudenthal and McLaughlin, The Social and Economic Roots of the Scientific Revolution, 1-40.

8 Representative of the British contributions in the 1930s is John D. Bernal, The Social Function of Science (London: Routledge, 1939). Reflections on their input are: Gary Werskey, The Visible College. The Collective Biography of British Scientific Socialists in the 1930s (New York: Holt Rinehart Winston, 1970); Cristopher A.J. Chilvers, "The dilemmas of Seditious Men: The Crowther-Hessen Correspondence in the 1930s," British Journal for the History of Science 36, no. 4 (2003): 417-35; Pnina G. Abir-Am, "The Biotheoretical Gathering, Trans-disciplinary Authority and the Incipient Legitimation of Molecular Biology in the 1930s: New Perspective on Historical Sociology of Science," History of Science 25, no. 1(1987): 1-70.

${ }^{9}$ Not by accident their works were recovered in the 1980s in a journal on the history of science. See Franz Borkenau, "The sociology of the mechanistic world-picture," Science in Context 1, no. 1 (1987): 109-27; and Henryk Grossmann, "The social foundation of mechanistic philosophy and manufacture," Science in Context 1, no. 1 (1987): 129-80.
} 
Harvard University, in September $1939,{ }^{10}$ and which points to the communication between two formerly disjointed spheres of knowledge-one stemming from the humanists and the other from the artisans and engineers - as the social roots of modern science. Later on, from the Frankfurt school came the pessimistic considerations of Max Horkheimer and Theodor Adorno in the Dialectic of Enlightenment (1947) in which they argued that the collapse of reason in totalitarian regimes resembled forms of superstition, out of which reason had supposedly emerged as a result of historical progress or development. Further, they stated that in the process of Enlightenment, modern philosophy had become over-rationalized and an instrument of technocracy. ${ }^{11}$

Voiced from a very different ideological stance, but influenced by Hessen's thesis, one also recalls Robert Merton's creating a connection between the emergence of modern science and the Puritan ethos, building on the thesis of the German sociologist Max Weber, ${ }^{12}$ and Merton's appeal for attention to be paid to the defining characteristics of the scientific ethos (universalism, communalism, impartiality and scepticism). ${ }^{13}$ Also, just on the brink of the 1930s, Abbot Usher published A History of Mechanical Inventions (1929), ${ }^{14}$ which together with Lewis Mumford's Technics and Civilization (1934), ${ }^{15}$ presented an innovative discourse on the role played by technology in shaping and being shaped by civilizations. Mumford specifically discussed the traditional historical timeline that associates a capitalist, industrialized, machineoriented economy, to the industrial revolution, pushing its roots back into the Middle Ages and stressing the relevance of political decisions and choices.

This thematic issue sprang from the session "The fabulous thirties in the history of science and technology" held at the 8th European Society for the History of Science's biennial meeting, which took place in London, in September 2018 and which was also proposed and organized

${ }^{10}$ Edgar Zilsel, "The Origins of William Gilbert's Scientific Method," Journal of the History of Ideas 2, no. 2 (1941): 1-32; Edgar Zilsel, "The Sociological Roots of Science," American Journal of Sociology 47, no. 2 (1942): 544-62; Edgar Zilsel, "The Genesis of the Concept of Physical Law," Philosophical Review 51, no. 3 (1942): 245-79; Edgar Zilsel, "The Genesis of the Concept of Scientific Progress," Journal of the History of Ideas 6, no. 3 (1945): 325-49; Edgar Zilsel, The Social Origins of Modern Science (Dordrecht: Kluwer Academic Publishers, 2000).

${ }^{11}$ Max Horkheimer and Theodor Adorno, Dialectic of Enlightenment (Stanford: Stanford University Press, [1947] 2002).

${ }^{12}$ Robert K. Merton, "Science, Technology and Society in Seventeenth Century England," Osiris 4 (1938): 360-632. On Merton's thesis see A. Rupert Hall, "Merton Revisited, or Science and Society in the 17th Century," History of Science 2 (1963): 1-15; I. Bernard Cohen, ed., Puritanism and the Rise of Modern Science: The Merton Thesis (New Brunswick: Rutgers University Press, 1990).

${ }^{13}$ Robert K. Merton, "The Normative Structure of Science," in The Sociology of Science: Theoretical and Empirical Investigations (Chicago: University of Chicago Press, 1973). Originally published as "A Note on Science and Technology in a Democratic Order," Journal of Legal and Political Sociology, 1, no. 1-2 (1942): 115-26.

${ }^{14}$ Abbot Usher, A History of Mechanical Inventions (New York: McGraw-Hill, 1929).

${ }^{15}$ Lewis Mumford, Technics and Civilization (New York: Harcourt, Brace and Co., 1934). 
by the guest editors. ${ }^{16}$ For various reasons, however, just one of the papers presented at the session is included here, having been reformulated in order to materialize the subsequent historiographical reflections by its author.

The aforementioned session and this issue bear witness to our long-time interest in the historiography of science and technology and the belief that knowing it is fundamental not only in itself, to chart the historiographical map of the discipline we embraced, but as a source, as already mentioned, of inspiration to assess the present historiographical predicaments the community of historians of science and technology finds itself in.

We are not interested in looking back at the past of the history of science and technology to quasi-prioritize issues and immerse ourselves in a frame of mind eager to assert "who said what" or "who said it first." We realize that ideas are continuously in flux: they circulate and recirculate, but always in radically different contexts. Echoing Marc Bloch, we claim that what is truly relevant is to understand how ideas flow and are appropriated in different historical contexts, ${ }^{17}$ or, going a step forward, it is relevant to analyse how concepts, when taken out of their initial contexts and reappearing in totally different scenarios, may acquire different meanings and bear fruitful and unexpected implications. ${ }^{18}$ To be able to understand ideas and concepts in context is, therefore, a deeply cultural undertaking and this has been the approach adopted by all the authors of this issue. We further claim that this undertaking is not necessarily antagonistic with an opportunistic stance, in which the past is examined with a view to the present. This has also been the aim of most of the authors of this issue, who believe that a scrutiny of past knowledge should not only be guided by present concerns, but that past knowledge can illuminate current predicaments.

The 1930s were indeed "fabulous" in terms of the audacity of proposals for the history of science and technology, when compared to previous disciplinary trends. In this thematic issue, authors discuss the first steps towards what later came to be called "social and cultural history of science and technology," which emerged out of different, non-convergent but not mutually exclusive, research avenues: Marxist history of science and technology, ${ }^{19}$ the Annales School, ${ }^{20}$ and continental historical and sociological epistemology. ${ }^{21}$ As a matter of fact, authors

\footnotetext{
${ }^{16}$ See sessions and abstracts of the 8th ESHS Conference at http://www.eshs.org/8th-ESHS-conferenceLondon-2018.html, accessed October 7, 2020.

${ }^{17}$ Marc Bloch, Apologie pour l'Histoire ou Métier d' Historien (Paris: Armand Colin, 1949), 23.

18 Kostas Gavroglu and Yorgos Goudarolis, Methodological Aspects of Low Temperature Physics, 18811956. Concepts out of Context(s) (Dordrecht: Springer Netherlands: 1989); Nancy J. Nersessian, Creating Scientific Concepts (Boston: MIT Press, 2008).

19 See notes 6 and 7 above.

20 Peter Burke, The French Historical Revolution: The Annales School 1929-1989 (Cambridge: Polity Press, 1990).

${ }^{21}$ Gary Gutting, ed., Continental Philosophy of Science (Oxford: Blackwell Publishers, 2005).
} 
addressed in this thematic issue were born in continental Europe, not only in Central Europe, but also in France, Italy and the Soviet Union, where they lived and worked before eventually migrating, often to the United States of America. As such, their contributions fall in what we may call "continental history of science and technology," in contrast to those stemming from the English-speaking world, which due to the historical development of the discipline, the political context of the Cold War, and their present hegemonic status, came to dominate the historiography of science. Such a classification extends the scope of Alberto Fragio's assessment of the continental history (and philosophy) of science in one of the papers in this issue. In fact, one of the most important aspects of Fragio's and Maria Paula Diogo's papers is the recovery of the French historiographic tradition, which began with Léon Brunschvicg and Abel Rey and the first generation of the Annales School, and extends to authors such as Hélène Metzger, George Canguilhem and Michel Foucault. While the authors' proposals discussed in this issue do not exhaust the diversity of suggestions put forward in the 1930s, we believe they offer a good glance at the decade's historiographical richness.

The Marxist history of science and technology is addressed in two papers: Pietro Omodeo's paper on Antonio Gramsci, in which the author addresses Gramsci's historico-political views on science and discusses how his culturalist approach to science did not renounce objectivity; and Giulia Rispoli and Gerardo Ienna's paper (to be included as part of this thematic issue in the next HoST issue), which focuses on the 1931 London conference and discusses not only Hessen's talk, but also other contributions, contextualizing the conference's aftermath in the lively British environment where Marxist views took hold. The contributions of the Annales School started with the publication of the French journal Annales d'histoire économique et sociale by Marc Bloch and Lucien Febvre in 1929. They are addressed by Diogo. She discusses how Bloch and Febvre considered the history of science and technology as an integral part of history at large and indissolubly connected to the intellectual context of a particular time period, defined by its material and mental tools. She gives special attention to their concepts of mentalités, histoire-problème, histoire totale (mentalities, history-problem, total history) and historical temporality. Finally, continental historical and sociological epistemology is addressed by Kathryn Olesko and by Fragio. Based on the ideas voiced in Schutz's The Phenomenology of the Social World (1932) and Fleck's Genesis and Development of a Scientific Fact (1935), Olesko embarks on a somewhat unexpected comparison between the similar approaches to the daily workings of science by the phenomenologist of society Alfred Schutz and the historical epistemologist Ludwik Fleck, certainly better known to historians of science than Schutz as 
one of the precursors of the historicist turn and even of social constructivism. ${ }^{22}$ She specifically addresses their belief that knowledge is sustained by communication between two or more persons; how interlocutors themselves are transformed through the acquisition of knowledge; and most importantly, how communication cultivates trust, especially in scientific results. Finally, Fragio offers an overview of European history and philosophy of science in the 1930s, focusing on the neo-Kantian Marburg School—represented by Ernst Cassirer, Alexandre Koyré, and Émile Meyerson-, who published a considerable part of their work on the history of physics in the 1930s, and finally Brunschvicg, in order to address the contributions of the philosopher Gaston Bachelard, whom Fragio considers one of the leading representatives of French historical epistemology. Fragio has two major aims in mind: on the one hand, to point out that the history of science, as an epistemological laboratory for the philosophy of science, goes back to the 1930s, and more specifically, to Bachelard's proposal, and on the other, to outline what continental philosophy of science is. Olesko's and Fragio's texts offer an alternative view to the dominant philosophical currents in science studies, in the 1930s. The authors they discuss anticipated the limits that logical positivism had imposed on our understanding of scientific rationality, which they considered only from an internal perspective, from the so-called "context of justification," leaving the "context of discovery" out of philosophical analysis. Several of the authors discussed in this special issue claimed to be presenting a new historical epistemology, by means of their work, based on the historicity of epistemic categories or scientific facts such as syphilis (Fleck), thermal propagation in solids (Bachelard), reflex (Canguilhem) or madness (Foucault).

The promise that the 1930s offered in the realm of the history of science and technology emerged from a deeply troubled political and economic context, troubled to such an extent that this decade is commonly remembered as "the terrible and dirty thirties." ${ }^{23}$ This decade was characterized by a global economic and political crisis, which culminated in World War II. The collapse of the international financial system, which began with the Wall Street Crash in 1929 and the economic breakdown associated with the Great Depression impacted globally, leading to widespread unemployment and poverty, especially in the United States of America and in Germany, which was still coping with the aftermath of the Great War. The Dust Bowl, the name given to the drought-stricken Southern Plains' region of the United States, which

22 Alfred Schutz, The Phenomenology of the Social World (Chicago: Northwestern University Press, 1967), originally published as Der sinnhafte Aufbau der sozialen Welt: Eine Einleitung in die verstehenden Soziologie (Vienna: Springer, 1932); Ludwik Fleck, Genesis and Development of a Scientific Fact (Chicago: University of Chicago Press, 1979), originally published as Entstehung und Entwicklung einer wissenschaftlichen Tatsache: Einführung in die Lehre vom Denkstil und Denkkollektiv (Basel: Schwabe, 1935).

${ }^{23}$ Piers Brendon, The Dark Valley: A Panorama of the 1930s (New York: Knopf, 2000); Mark Grossman, Encyclopedia of the Interwar Years: From 1919 to 1939 (New York: Facts on File, 2000); John A. Garraty, The Great Depression: An Inquiry into the Causes, Course, and Consequences of the Worldwide Depression of the Nineteen-Thirties, as Seen by Contemporaries (New York: Harcourt Brace Jovanovich, 1986). 
contributed to the nickname the "Dirty Thirties," accentuated the scarcity of wealth. The situation was worsened by President Herbert Hoover's failed attempt to balance the nation's budget by increasing taxes, a measure which was then counteracted by his successor, President Franklin D. Roosevelt, who orchestrated the New Deal (1933), with the aim of restoring prosperity to the United States of America. In the face of a deep crisis, politicians across the world, and not just in the United States, paid special attention to the resolution of economic problems, viewing them as crucial to their political acceptance and success.

The sweeping financial and economic backlash was accompanied by a disbelief in liberal democracy and the concomitant rise of dictatorial regimes, both fascist and communist, in many countries around the globe. The election of Adolf Hitler in Germany and the onset of the Third Reich was dominated by a discriminatory agenda against Jews and other ethnic minorities, and a dictatorial and expansionist program, which led to the outbreak of World War II, on 1 September 1939, despite the League of Nations' appeals for worldwide peace.

The political climate preceding the war witnessed a massive migratory movement of European intellectuals and scientists, who fled initially from Austria and Germany, and then from countries invaded in succession by the Nazis. The death of Moritz Schlick, one of the leading figures of logical positivism, at the hands of a Nazi student in Vienna, in 1936, is a symptomatic episode of what intellectuals were experiencing in Central Europe during the 1930s. The "brain-drain" of European expertise to the United States of America acted as a springboard for its emergence as a major scientific hub. While the geography of the sciences changed drastically, disciplinary boundaries were crossed at an increasing pace with the rise of the importance of molecular transformations in biology and the emergence of various "in-between" disciplines. ${ }^{24}$ The sciences' world was further troubled by the enigmatic microscopic world of quantum mechanics, with its new laws defying common sense and simultaneously putting into question major former structural characteristics of the sciences, such as determinism, locality and the object (nature)-subject independence. This new scientific worldview was epitomized by the Einstein-Podolsky-Rosen Paradox and its more popular version, the Schrödinger's cat thought experiment, both put forward in $1935 .{ }^{25}$

\footnotetext{
24 From the 1930s onwards several in-between disciplines emerged: quantum chemistry and computational chemistry, biophysics, biochemistry, materials science, astrophysics, astrobiology, biotechnology, bioengineering and genetic engineering, computer science, computational physics, physical medicine, and industrial science.

25 Albert Einstein, Boris Podolsky, and Nathan Rosen, "Can Quantum-Mechanical Description of Physical Reality be Considered Complete?" Physical Review 47, no. 10 (1935): 777-80; Erwin Schrödinger, "Die gegenwärtige Situation in der Quantenmechanik" [The Present Situation in Quantum Mechanics], Naturwissenschaften 23, no. 48 (1935): 807-12.
} 
Other techno-scientific novelties came to the forefront during the "long 1930s," ${ }^{26}$ preparing the ground for the terrible dénouement of World War II, and the subsequent political tension between East and West, defining the Cold War. They included the discovery of Pluto, another planet in the solar system, the work on uranium fission of Lise Meitner, Otto Hahn, and Fritz Strassmann, the potentialities offered by radar to scrutinize the globe on an unprecedented scale, to the first inroads in computer building with $\mathrm{Z1}$ by Zuse, the unmatched connecting ability afforded by intercontinental aviation and radio waves, and, later on, the first steps in the intercontinental ballistic missile program by the Soviet rocket engineer Sergei Koroliov and in the development of rocket technology by the German aerospace engineer Wernher von Braun. Previously, new vistas were offered to the masses by the world's love affair with Kodachrome and by the creation of a host of superheroes in movies. Simultaneously scared by real political powers and thrilled by unreal superpowers, the public's intermingling of reality and fiction was incarnated in the reaction to the now famous CBS radio transmission "The war of the worlds" (1938), narrated by Orson Wells.

The fate of most of the main actors in the papers referenced in this issue reflected to an agonizing degree the real drama unfolding across Europe: ${ }^{27}$ while deputy director of the Physics Institute in Moscow, just three years after the 1931 London conference, Hessen was accused of infidelity to orthodox Marxism (to which his internationalism and defence of general relativity and quantum mechanics were not alien and were considered to be reactionary expressions of bourgeois science), arrested during Stalin's Great Purge in 1936, secretly tried by a military tribunal and executed on 20 December 1936; Nikolai Bukharin, the head of the Soviet delegation at the London conference, was arrested in 1937, charged of conspiracy against the Soviet state and executed in March 1938; Gramsci could not resist the Italian fascist prisons, and died in 1937; the Polish Jewish immunologist Fleck managed to survive the concentration camps; Bloch joined the French resistance when Germany invaded Vichy France in 1942, but was captured in Lyon and executed in 1944. Many emigrated to the United States of America following the Anschluss (annexation) of Austria to the Third Reich in 1938. Such was the case of many members, including Horkheimer and Adorno, of the Frankfurt Institute for Social Research dismantled by the Nazis; or of Schutz who fled Austria to seek asylum in allied countries, first in Paris in 1938, then moving to the United States of America in 1939; or of various intellectuals of socialist and communist leanings of the Vienna circle, among whom stood Zilsel, who emigrated first to Britain and then to the United States in 1939, committing

26 "The 1930s Science and Technology: Chronology," Encyclopedia.com. https://www.encyclopedia. $\mathrm{com} /$ social-sciences/culture-magazines/1930s-science-and-technology-chronology, accessed October 7, 2020 .

27 Biographical details on the main actors discussed in this thematic issue are included in the papers and can also be accessed in standard biographical sources including the Britannica Online Encyclopedia. 
suicide in 1944. In contrast, Bachelard's and Febvre's life courses were relatively untroubled by war hardships, although their anti-Nazi positions were well-known.

The terrible context the above men found themselves in impacted not only on their lives but molded also their theoretical musings. The political, economic, geographic, ideological and disciplinary contexts shaping their various historiographical proposals are amply debated in the papers integrating this issue. ${ }^{28}$ The impact of the historical context was quite evident in the case of Hessen: not only the Soviet context shaped his historiographical considerations, but his influence on the left wing of British science quickly translated into works marked by historical materialism, such as Bernal's The Social Function of Science (1939) and later on major research projects, such as Needham's Science and Civilization in China (1954-present). ${ }^{29}$ Omodeo shows how Gramsci's views on science, epistemology, society and politics voiced particularly clearly in the Notebook 11 of his Prison Notebooks, though written in the stark isolation of prison, were deeply conversant with the international debates going on among Marxist intellectuals: particular attention was given to ideas voiced by Nikolai Bukharin in Historical Materialism (1921) and in his lecture at the 1931 London Conference. ${ }^{30}$ Diogo deconstructs the pervasive narratives on marginality and peripheralization associated to Bloch and Febvre, who taught at the University of Strasbourg in Alsace, far away from the central University of Sorbonne in Paris, but close to Germany and to the German culture, assessing how geographical locality shaped their musings. Olesko implicitly reveals how the Great War and the social and scientific context of the inter-war period, the seed of twentieth-century totalitarianism, conditioned Fleck's and Schutz's understanding of the social dimension of knowledge. Grounded on a philosophical methodology, as opposed to a more historicallyoriented one, Fragio examines the continental philosophy of science, in order to contextualize Bachelard's ideas in the French neo-Kantian philosophy of science.

There is a common denominator, shared by all proposals, that distanced them from former positivist ones and accounts for their complete originality: it is the prominence given to historical time and the historicity of scientific and technical knowledge, at the same time as the downplaying of great personalities, inventions and discoveries. By taking the agency of historical time seriously, the multifarious contexts (social, political, cultural, economic, religious, etc.) in which scientific processes unfold and actors move about and interact took on an unanticipated relevance; the genesis and development of scientific facts became a historical

28 This is also particularly evident in the case of Zilsel: Zilsel's thesis on the role of artisans may be interpreted as a reflection of his own life, dominated by marginalisation and oblivion.

29 Bernal, The Social Function of Science; Joseph Needham, ed., Science and Civilisation in China Book Series (Cambridge: Cambridge University Press, 1954-1995). Needham's project continued to be developed until today, even after his death in 1995.

${ }^{30}$ Nikolai Bukharin, Historical Materialism: A System of Sociology (New York: International Publishers, 1925). 
problem; the emphasis on precursors lost historical pertinence, leaving room for a contextual explanation of actors' accomplishments; the present became an inspiration for historical queries; and finally a distinctive historical style emerged in the formulation of philosophical problems, providing the groundwork for what is often identified as historical epistemology.

The context of the 1930s also created an impact on the subsequent circulation, deferment or rejection of proposals put forward at the time. If one assesses Hessen's views in the Soviet intellectual debates of the time, ${ }^{31}$ one realizes that his intermingling of Marxism with considerations on science, tinged by Machism, were clearly unacceptable to orthodoxy, making it easier to understand not only his 1931 presentation as an adjustment to a hostile Soviet environment, in an attempt to prove his allegiance to dialectic materialism, but also the inability to avoid subsequent reprisals. On the other hand, the Cold War environment explains the rejection of Hessen's thesis among American historians of science in the 1950s and 1960s. ${ }^{32}$ In addition to the long and costly editing of his prison notebooks, it took decades before Gramsci's ideas were appropriated and blended into studies of popular culture and critical theory, in contributions and refined analyses, including a rich amalgamation of concepts and notions. Similarly, Zilsel's ideas about the materialistic origins of modern science were rejected for a long time, not only due to the academic context where the most orthodox vision of modern science prevailed (which attributed the Scientific Revolution to the great geniuses of modernity), but also due to the political context in America following Zilsel's death, in which anti-communist policies of McCarthyism became dominant. Bloch's and Febvre's famous discussion on suspending or continuing to publish the Annales during the occupation of France by the Nazis, shows the complexity of the decisions that had to be made, whilst balancing the survival of scientific agendas and the moral imperative of asserting political stances. In the same vein, the cultural devastation following World War II accounts for the long decades of oblivion into which Fleck's Genesis and Development of a Scientific Fact (1935) fell. Something similar happened to Bachelard, whose work on the formation of the scientific spirit, La formation de l'esprit scientifique: contribution à une psychanalyse de la connaissance objective (1938), anticipated many ideas of future historicists: the context of its publication, in French, in a period in which the philosophy of science was dominated by Austrian and Anglo-Saxon logical empiricism, greatly delayed its being noticed. ${ }^{33}$

Finally, the authors of most of the papers, adopted an opportunistic approach when looking back at the 1930s, advocating their appropriation in order to illuminate present problems

\footnotetext{
${ }^{31}$ Gerardo Ienna and Giulia Rispoli, "Boris Hessen at the Crossroads of Science and Ideology," Society and Politics 13, no. 1 (2019): 37-63, on 49-57.

32 Ibid., esp. 45 and 48.

${ }_{33}$ Gaston Bachelard, La formation de l'esprit scientifique: contribution à une psychanalyse de la connaissance objective (Paris: J. Vrin, 1938).
} 
and thereby illustrating the crucial role of historians of science and technology as "organic intellectuals," to borrow one of Gramsci's central concepts. ${ }^{34}$ Here are two especially striking examples: Omodeo's discussion of Gramsci's struggle with scientific objectivity and Olesko's analysis of Schutz's and Fleck's advocacy of the role of communication in building trust in scientific results. They stem from their conviction that the relevance of scientific objectivity and of trust in science have acquired a new urgency in light of on-going debates surrounding the Covid-19 pandemic, the role of scientific facts and narratives, presidential elections in the USA, the proliferation of fake news and the stress on "post-truths"; to these we venture to add political disputes between the countries of northern and southern Europe, in the form of mistrust, in dealing with recent economic crises, BREXIT or the refugee crisis.

To conclude, we are convinced that an examination of the 1930s in the history of science still offers many rewards. While this is, indeed, an overwhelming undertaking, we hope this issue proves to be a small but relevant contribution to an improved and multifaceted knowledge of this, on the one hand, terrible decade, whilst on the other, fabulous one, due to the emergence of new and fruitful lines of research in the field of the history of science and technology.

\section{Acknowledgments}

We thank those who participated in the session "The fabulous thirties in the history of science and technology," held at the $8^{\text {th }}$ European Society for the History of Science's biennial meeting, for their comments; the authors, for having accepted to participate in this venture; and referees who helped in shaping this issue. We thank Maria Paula Diogo for discussions on the history of the history of technology in the thirties; and finally, M. Luísa Sousa, the HoST Chief Editor throughout the conception and implementation of this issue, who is now terminating her mandate, for all her enthusiastic support and professionalism.

\section{Competing interests}

The authors declared that no competing interests exist.

\section{Funding}

Ana Simôes thanks the Fundação para a Ciência e a Tecnologia, Portugal, for financial support under project UIDB/00286/2020. Antonio Sánchez thanks the Ministerio de Ciencia, Innovación y Universidades, for financial support under project PID2019-111054GB-I00.

${ }^{34}$ See Antonio Gramsci, Selection from Prison Notebooks (London: Lawrence and Wishart, 1971). 